\title{
Çanakkale ili börülce üretim alanlarında Hıyar mozaik virüsü (Cucumber mosaic virus; CMV)'nün tespiti ve kılıf protein genine göre moleküler karakterizasyonu
}

\author{
Ali KARANFÍL ${ }^{1}$
}

\author{
$\underline{\text { Savaș KORKMAZ }}^{1}$
}

\begin{abstract}
Detection and molecular characterization based on coat protein gene of Cucumber mosaic virus (CMV) from cowpea production fields of Çanakkale province in Turkey
\end{abstract}

In 2015-2016, surveys were carried out in areas of Çanakkale province where cowpea and bean were cultivated. Twenty-two samples (14 bean and 8 cowpea) showing virus and virus-like symptoms were collected from these areas. The collected samples were tested by DAS-ELISA to determine the presence of Cucumber mosaic virus (CMV) infection and 6 samples out of 22 were found to be infected with CMV. While the determined all CMV infection was found in cowpea samples, there was no infection found in bean samples. Coat protein (CP) gene of samples infected with CMV was amplified with RT-PCR and corresponding bands of $638 \mathrm{bp}$ were obtained from all of them. RT-PCR products of CWP17 isolate chosen from infected samples randomly was purified and sequenced. Sequence data of CWP17 isolate was deposited (accession number: KY474380) in GenBank. Results of multiple sequence alignment analysis, CWP17 isolate was found to be identical $80-99 \%$ and $90-100 \%$ with world CMV isolates in nucleotide and amino acid level, respectively. Also, CWP17 isolates was found in Subgroup IB accordingly phylogenetic tree created. With carrying out this study, CMV infection was the first time detected in commercial cowpea production areas in Turkey. In addition, the first molecular characterization work was carried out in legume production areas of Turkey.

Keywords: DAS-ELISA, RT-PCR, phylogenetic, sequencing, CP

\footnotetext{
${ }^{1}$ Çanakkale Onsekiz Mart Üniversitesi, Ziraat Fakültesi, Bitki Koruma Bölümü, Çanakkale Sorumlu yazar (Corresponding author) e-mail: skorkmaz@comu.edu.tr Alınış (Received): 09.02.2017, Kabul ediliş (Accepted): 26.05.2017
} 


\section{$\ddot{\mathbf{O Z Z}}$}

$\mathrm{Bu}$ çalışma kapsamında 2015-2016 yıllarında Çanakkale ilinin börülce ve fasulye yetiştiriciliği yapılan alanlarına arazi çıkışları yapılarak virüs ve virüs benzeri belirtiler gösteren 14 fasulye, 8 börülce olmak üzere toplam 22 bitkiden örnekler alınmıştır. Toplanan örnekler Hiyar mozaik virüsü (Cucumber mosaic virus; CMV) varlığını belirlemek için DAS-ELISA ile testlenmiş ve 6 örnek CMV ile enfekteli bulunmuştur. Enfekteli bulunan tüm örnekler börülce bitkisinden elde edilirken, fasulye bitkilerinde enfeksiyon tespit edilememiştir. Elde edilen CMV izolatlarının kılıf protein (CP) gen bölgesi, gen spesifik primerler kullanılarak çoğaltılmış ve izolatların tamamında 638 bp büyüklükte $\mathrm{CP}$ genine spesifik ürün elde edilmiştir. CMV izolatları arasından CWP17 tesadüfi olarak seçilerek RT-PCR ürünleri purifiye edilmiş ve kısmi baz dizisi analizi gerçekleştirilmiştir. CWP17 izolatına ait sekans verisi KY474380 erişim numarası ile gen bankasına kaydedilmiştir. Gerçekleştirilen çoklu dizi analizleri sonucunda CWP17 izolatının dünya CMV izolatları ile nükleotid düzeyinde \%80-99, aminoasit düzeyinde ise \%90-100 benzerlik gösterdiği saptanmıştır. Oluşturulan filogenetik ağaçlar ile de CWP17 izolatının alt grup IB'de yer aldığı belirlenmiştir. Gerçekleştirilen bu çalışma ile Türkiye'de ilk defa CMV enfeksiyonu ticari börülce üretim alanlarında tespit edilmiştir. Ayrıca ülkemizde ilk kez baklagil üretim alanlarında CMV enfeksiyonunun moleküler karakterizasyonu gerçekleştirilmiştir.

Anahtar kelimeler: DAS-ELISA, RT-PCR, filogenetik, sekans analizi, CP

\section{GíRiș}

Hiyar mozaik virüsü (Cucumber mosaic virus; CMV), ilk olarak hyar (Cucumis sativus L.) bitkisi üzerinde 1934 yılında Amerika'da Price tarafından rapor edilmiştir. $\mathrm{Bu}$ virüs Bromoviridae familyası içerisinde yer alan Cucumovirus cinsinin en önemli üyelerinden birisi olarak kabul edilmektedir. CMV, TMV'den sonra en fazla konukçu dizisine sahip virüs olarak bilinmektedir. Ayrıca diğer virüs hastalıklarından, sahip oldukları konukçu dizisi ve sayısı bakımından, daha önemli olarak görülmektedir. Virüs, 100 familyaya giren 1200'den fazla bitkiyi enfekte edebilme yeteneğindedir (Zitter and Murphy 2009). CMV, zarf içermeyen, yaklaşık olarak 29-30 nm çapında izometrik şekilli, üç parçalı (+) ssRNA genomuna sahiptir (Palukaitis and Garcia-Arenal 2003). Bu 3 parçalı genom RNA1 ( 3350 nt), RNA2 ( 3050 nt) ve RNA3 ( 2200)'den oluşmaktadır. Ayrıca RNA3'ün bazen dördüncü bir RNA ( 1030 nt) içerebildiği de belirtilmiştir. RNA1 tek bir protein kodlamaktadır. RNA1'in kodladığı bu protein 1a olarak ifade edilmiş ve genomun viral replikasyonu için hayati öneme sahip olduğu bildirilmiş̧ir. RNA2 ise $2 a$ ve $2 b$ olmak üzere 2 protein kodlamaktadır. 2a proteini viral replikasyonla ilişkilendirilirken, $2 \mathrm{~b}$ proteini ise enfeksiyon sırasında konukçunun kendini savunmak amacı ile ürettiği gen sessizleştirme sinyallerini engellemektedir. Ayrıca $2 \mathrm{~b}$ proteini virüsün uzun mesafelere taşınması ve simptom oluşumunda da etkilidir. Son olarak RNA3 ise 3a ve k1lıf proteini olmak üzere 2 protein kodlamaktadır. RNA3'ün kodladığı bu 3a proteininin virüsün hücreden hücreye hareketinden sorumlu hareket proteini olduğu belirtilmiştir (Zitter and Murphy 2009). Ayrıca 
etmen 75 'den fazla yaprak biti türü ile non-persistent olarak taşınmaktadır (Palukaitis et al. 1992).

CMV izolatlarının sınıflandırılmasının geçmişte; serolojik ilişkiler ve izolatların göstermiş oldukları nt benzerlik oranlarına dayanarak alt grup I ve alt grup II olmak üzere yapıldığ 1 belirtilmiştir (Palukaitis et al. 1992). Son yıllarda çok sayıda CMV izolatının CP genlerinin ve 5' okuma yapılmayan bölgelerinin analizi ile alt grup I'in IA ve IB şeklinde 2'ye ayrıldığı görülmektedir (Roossinck et al. 1999). CMV alt grup I ve II arasındaki nt düzeyinde benzerlik oranlarının 69 ile 77 arasında değiş̧tiği belirtilirken, grupların kendi içlerinde ise benzerlik oranlarının \%90'nın üzerinde olduğu belirtilmiştir (Palukaitis et al. 1992). Ayrıca CMV IA ve II alt gruplarının tüm dünya izolatlarından oluşabileceği bildirilirken, IB alt grubunun ise genellikle Asya izolatları ile sınırlandığı ifade edilmiştir (Roossinck 2002).

Türkiye'de gerçekleştirilen birçok çalışmada CMV varlığ farklı konukçularda tespit edilmiştir (Gümüş ve ark. 2004, Beler ve Açıkgöz 2005, Çağlar 2006, Ergun et al. 2013, Erkan ve ark. 2013, Sarı 2015, Sertkaya 2015, Gökdağ ve ark. 2016, Karanfil ve ark. 2016). Türkiye'de daha önce börülce virüs hastalıkları ile yapılmış kapsamlı bir çalışma bulunmamakla birlikte, tohum patojenlerinin inaktivasyonu ile ilgili bir çalışmada börülce tohumlarında CMV enfeksiyonu tespit edilmiştir (Paylan et al. 2014). Diğer bir çalışmada ise fasulye alanlarında CMV varlığı tespit edilmiş, fakat karakterizasyonu gerçekleştirilmemiştir (Kilic et al. 2015). Bu nedenle çalışmanın amacı, ticari üretim yapılan börülce ve fasulye alanlarında CMV varlığının tespit edilerek, moleküler karakterizasyonunun yapılması şeklinde planlanmiştır.

\section{MATERYAL VE METOT}

\section{CMV izolatları}

Arazi çalışmaları 2015-2016 yıllarında Çanakkale ilinin Ezine, Bayramiç ve Ayvacık ilçelerinde gerçekleştirilmiştir. Şiddetli virüs ve virüs benzeri belirtiler gösteren 14 fasulye, 8 börülce örneği olmak üzere toplamda 22 örnek alınmıştır. Toplanan örneklerdeki CMV varlığı DAS-ELISA ile belirlenmiştir.

DAS-ELISA testi Clark and Adams (1977)'nin belirttiği temel yöntem esas alınarak Bioreba (İsviçre) firmasından sağlanan kitler ile üretici firmanın önerileri doğrultusunda gerçekleştirilmiştir. DAS-ELISA testlerinde pozitif olarak bulunan tüm örnekler RT-PCR ile analiz edilmiştir.

RT-PCR analizinde ise ilk olarak RNeasy Mini Kit (Qiagen, Kanada) ile toplanan örneklerden total RNA ekstrasyonu yapılmıştır. İkinci aşamada, elde edilen total RNA'lardan TaKaRa (Japon) firmasından sağlanan kitler ile 657 bp'lik CP geninin 638 bp kısmı amplifiye edilmiştir. Bu amaçla kitlerin sağlandığı firmanın önerileri doğrultusunda total RNA thermal cycler'da (Bio-Rad, ABD) $65{ }^{\circ} \mathrm{C}$ 'de $5 \mathrm{dk}$ 
Çanakkale ili börülce üretim alanlarında Hıyar mozaik virüsü (Cucumber mosaic virus; CMV)'nün tespiti ve kılıf protein genine göre moleküler karakterizasyonu

bekletilmiş ve hemen ardından buza alınarak denatürasyon aşaması tamamlanmıştır. Denatüre edilmiş RNA'lardan cDNA'ların sentezlenmesi amacı ile RT karışım hazırlanmış ve $30^{\circ} \mathrm{C}^{\prime} \mathrm{de} 10 \mathrm{dk}, 42{ }^{\circ} \mathrm{C}$ 'de $45 \mathrm{dk}, 70{ }^{\circ} \mathrm{C}$ 'de $15 \mathrm{dk}$ ve $+4{ }^{\circ} \mathrm{C}$ 'de sonsuz $(\infty)$ şekilde programlanan thermal cycler'da komplementer DNA (cDNA)'lar sentezlenmiştir. RT-PCR çalışmalarının son aşamasında elde edilen cDNA'ların amplifikasyonu gerçekleştirilmiştir. $\mathrm{Bu}$ amaçla hazırlanan PCR karışımına cDNA'lar eklenerek $94{ }^{\circ} \mathrm{C}$ ' de $3 \mathrm{dk}$; 40 defa tekrarlanan $94{ }^{\circ} \mathrm{C}$ ' de $30 \mathrm{sn}$, $55{ }^{\circ} \mathrm{C}$ 'de 30 sn ve $72{ }^{\circ} \mathrm{C}$ 'de $45 \mathrm{sn} ; 72{ }^{\circ} \mathrm{C}$ 'de $5 \mathrm{dk} ;+4{ }^{\circ} \mathrm{C}^{\prime}$ de sonsuz $(\infty)$ şeklinde programlanan thermal cycler'a konularak $\mathrm{CMV} \mathrm{CP}$ genleri tasarlanan primer çiftleri ile çoğaltılmıştır (SK5 CMV-F: ATGGACAAATCTGAATCAACC ve SK6 CMV-R: GATGTGGGAATGCGTTGGTGC). Son olarak elde edilen PCR ürünleri 100-1000 bp DNA büyüklük markırlarıyla birlikte \%1.5'lik agaroz jel içinde 100 voltta, 45 dakika ayrıştırılıp EtBr ile boyandıktan sonra jel görüntüleme cihazında (Major Science UVdi, Tayvan) hedef virüsün k1lif protein genine ait 638 bp'lik bantlar görüntülenmiştir. Moleküler karakterizasyon için pozitif olarak bulunan izolatlar arasından CWP17 izolatı tesadüfi olarak seçilerek sekans analizi için kullanılmıştır.

Bu amaçla CWP17'nin RT-PCR ürünleri EZ-10 Column PCR purifikasyon kiti (BioBasic, Canada) ile üretici firmanın önerileri doğrultusunda purifiye edilmiştir. Purifiye edilen RT-PCR ürününün, Refgen Biyoteknoloji (Ankara, Türkiye) firmasından hizmet alımı ile çift yönlü olarak sekans analizi gerçekleştirilmiştir.

\section{Benzerlik, filogenetik ve evrimsel farklılık analizleri}

CWP17 izolatına ait ham sekans verileri CLC Main Workbench (V.7.7.3) programında analiz edilerek, benzerlik ve filogenetik analizler için hazır hale getirilmiştir. Daha sonra bu CMV izolatına ait elde edilen konsensus dizi NCBI (National Centre for Biotechnology Information)'dan indirilen diğer CMV izolatlarına ait CP sekans verileri ile birlikte filogenetik ağaçların oluşturulmasında kullanılmıştır (Çizelge 1). Bu amaçla CWP17 CP genlerine ait nükleotid dizileri CLC Main Workbench programında ClustalW ile çoklu dizi karșılaştırması yapılarak birbirleriyle ve dünya izolatlarıyla olan nt ve a.a. düzeyindeki benzerlik oranlar1 tespit edilerek Sequence Demarcation Tool, version 1.2 (SDTv1.2) kullanılarak renklendirilmiş matrix olarak elde edilmiştir (Muhire et al. 2014). CWP17 izolatının filogenetik ilişkileri de aynı programda Neighbor-joining ve UPGMA metoduyla kiamura iki algoritmas1 uygulanarak 1000 tekrarlı bootstrap analizi ile belirlenmiştir. Oluşturulan filogenetik ağaçlarda Peanut stunt virus; PSV (GenBank accession no: U15730) dış grup olarak filogenetik ağacın doğruluğunu arttırmak amacı ile kullanılmıştır. Filogenetik ağaçta oluşan gruplara göre izolatlar gruplandırılarak Mega7 programında grup içi ve arasından göstermiş olduğu evrimsel farklılık oranları belirlenmiştir (Kumar et al. 2016). 
Çizelge 1. Moleküler karakterizasyon çalışmalarında kullanılan Türk ve Dünya izolatlarına ait bazı bilgiler

\begin{tabular}{|l|l|l|l|}
\hline $\begin{array}{l}\text { Genbankası Erişim } \\
\text { Numarası }\end{array}$ & Izolat/Streyn & Orijin & Alt Grup* \\
\hline AF198103 & LY & Avustralya & II \\
\hline AF063610 & S & Güney Afrika & II \\
\hline AF127976 & LS & ABD & II \\
\hline HG965199 & YAL & İtalya & IA \\
\hline D00385 & O & Japonya & IA \\
\hline D10538 & Fny & ABD & IA \\
\hline AJ276481 & Mf & Güney Kore & IA \\
\hline U20219 & Ixora & Filipin & IB \\
\hline KJ746022 & YB6 & Çin & IB \\
\hline AJ810259 & KS44 & Tayland & IB \\
\hline HE962480 & Vir & Fransa & IB \\
\hline JX025993 & Khn1 & İran & IB \\
\hline FN554688 & 17Huahine & Frans1z Polinezyas1 & IB \\
\hline DQ285569 & - & Hindistan & IB \\
\hline KY474380 & CWP17 & Türkiye & IB \\
\hline
\end{tabular}

*Referans ve oluşturulan filogenetik ağaca göre alt gruplar.

\section{SONUÇLAR VE TARTIŞMA}

Gerçekleştirilen arazi çalışmaları kapsamında 22 virüs ve virüs-benzeri simptom gösteren fasulye (14 örnek) ve börülce (8 örnek) örneği toplanmıştır. Toplanan örneklerin DAS-ELISA ile testlenmesi sonucunda 6 örneğin CMV ile enfekteli olduğu tespit edilmiştir (Çizelge 2).

Çizelge 2. Çanakkale ilçelerinden toplanan ve Hiyar mozaik virüsü (Cucumber mosaic virus; CMV) ile enfekteli bulunan örnek sayıları

\begin{tabular}{|l|c|c|c|c|}
\hline \multirow{2}{*}{ Çanakkale İlçeleri } & \multicolumn{2}{|l|}{ Toplanan Örnek Sayısı } & \multicolumn{2}{l|}{ Enfekteli örnek sayısı } \\
\cline { 2 - 5 } & Fasulye & Börülce & Fasulye & Börülce \\
\hline Ayvacık & 2 & 6 & - & 4 \\
\hline Bayramiç & 8 & - & - & - \\
\hline Ezine & 4 & 2 & - & 2 \\
\hline Toplam & 14 & 8 & - & 6 \\
\hline
\end{tabular}

CMV enfeksiyonu tespit edilen örneklerin hepsini börülce örnekleri oluştururken, fasulye örneklerinde CMV enfeksiyonuna rastlanılmamıştır. Bu sonuçla toplanan örneklerdeki CMV enfeksiyon oranı \%27 olarak bulunurken, yalnız börülce örneklerinde ise $\% 75$ olarak tespit edilmiştir. CMV ile enfekteli olduğu belirlenen bitkilerde en s1k görülen simptomların ise yapraklardaki şekil bozuklukları ve hafif kıvrılmalar olduğu görülmüştür (Şekil 1). Toplanan tüm örneklerin virüs ve virüs benzeri simptom göstermesine rağmen, örneklerin hepsinde CMV enfeksiyonunun tespit edilememesi ise; bu örneklerde fasulye ve börülce bitkilerini enfekte eden 
Çanakkale ili börülce üretim alanlarında Hıyar mozaik virüsü (Cucumber mosaic virus; CMV)'nün tespiti ve kılıf protein genine göre moleküler karakterizasyonu

diğer virüslerin varlığından kaynaklanabileceği düşünülmektedir (Kutluk Y1lmaz ve ark. 2002, Güzel and Arlı-Sökmen 2003).

Çulal-Kılıç ve Yardımcı (2012) ise Burdur Çine Ovası fasulye üretim alanlarında CMV enfeksiyonunu araștırmak amacı ile bir çalıșma yürütmüșlerdir. Gerçekleştirdikleri bu çalışmada kloroz, mozaik, damar bantlaşmaları, yapraklarda deformasyon, bitki boyunda kısalma, damarlarda renk açılmaları, damar çekilmesi gibi simptomların CMV enfeksiyonundan kaynaklanabileceğini belirtmişlerdir. Gerçekleştirilen bu çalışma kapsamında CMV ile enfekteli bulunan börülce bitkisindeki simptomlar Çulal-Kılıç ve Yardımcı (2012)'nın çalışmasına paralellik göstermektedir.

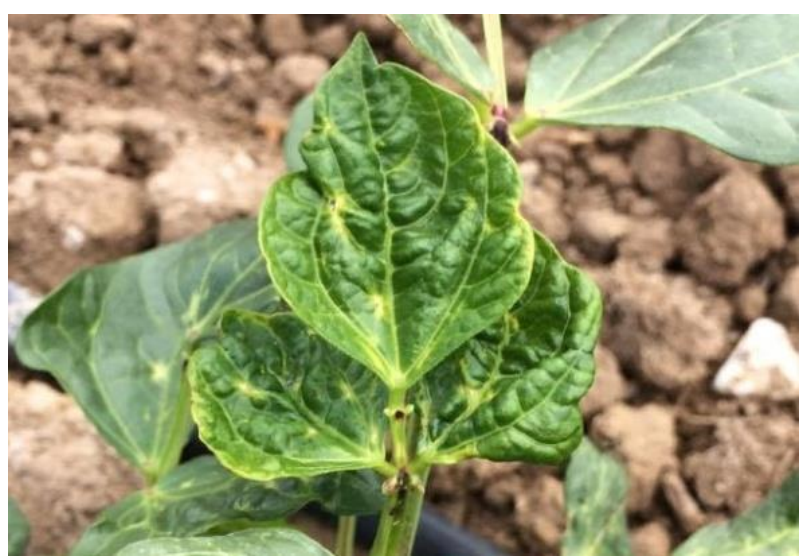

Şekil 1. Araziden toplanan ve Hiyar mozaik virüsü (Cucumber mosaic virus; CMV) ile enfekteli bulunan börülce bitkisinde yapraklarda şekil bozuklukları

Mohammadi et al. (2016) İran'da sebze üretim alanlarında CMV ile birlikte 3 farklı virüsün enfeksiyon durumlarının tespiti amacı ile gerçekleştirmiş oldukları çalışmada virüs ve virüs benzeri simptom gösteren farklı sebzelerden 100 yaprak örneği almışlar ve topladıkları bu örneklerin \%46'sının CMV ile enfekteli olduğunu bildirmişlerdir. Ayrıca araştırmacılar CMV'nin enfeksiyon durumları araștırılan 4 virüs içinde en yüksek enfeksiyon oranına sahip olan virüs olduğunu bildirmişlerdir. Bu bilgiler 1şı̆̆ında, farklı araştırmacıların gerçekleştirmiş olduğu çalışmalarda da CMV'nin birçok farklı bitkide yüksek oranlarda enfeksiyonlar meydana getirebileceği bildirilerek, bu çalışma kapsamında elde edilen CMV enfeksiyon oranını destekleyen paralel sonuçlar elde edilmiştir (Erkan ve ark. 2013, Kilic et al. 2015).

Enfekteli olarak bulunan $6 \mathrm{CMV}$ izolatının CP genleri RT-PCR ile çoğaltılarak, 638 bp'lik CMV CP genlerine karşıllk gelen bantlar tüm pozitif örneklerden elde edilmiştir (Şekil 2). RT-PCR ile CP genleri çoğaltılan izolatlar arasından CWP17 (Şekil 2'de 3 numaralı örnek CWP17 olarak isimlendirilmiştir) tesadüfi olarak seçilerek sekans analizi gerçekleştirilmiştir. 
Sekans analizi sonucunda elde edilen çift yönlü nükleotid dizilerinin birleştirilmesi sonucunda CLC Main Workbench programında dizileme kromatogramı kötü olan nükleotid dizileri (her iki uçtan yaklaşık olarak 30 nükleotid) kesilip atılmış ve 578 bp'lik CMV CP genine ait nükleotid dizisi elde edilmiştir. Elde edilen CMV CP genine ait 578 bp'lik nükleotid ve bu diziye göre çıkarılan amino asit yapıları üzerinden CWP17'nin dünya izolatları ile göstermiş olduğu benzerlik oranları ve filogenetik ilişkileri belirlenmiştir.

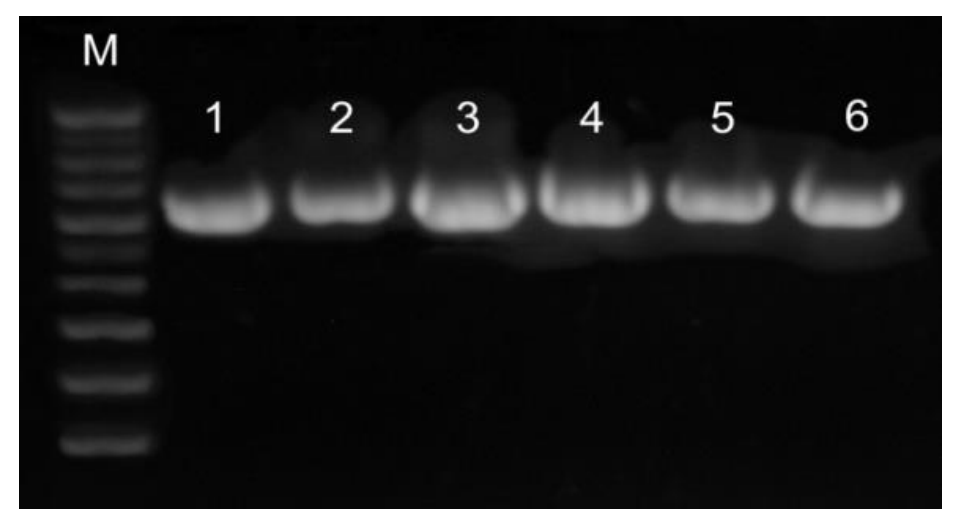

Şekil 2. Kıllıf protein geninin RT-PCR ile belirlenmesi (M: $1 \mathrm{~kb}$ DNA ladder (BioBasic, Kanada) 1, 2, 3 (CWP17) ve 4: Ayvacık-Çanakkale; 5, 6: Ezine-Çanakkale).

Gerçekleştirilen nt dizi analizleri sonucunda CWP17 izolatının dünya izolatları ile nükleotid ve amino asit düzeyinde sırası ile \%80-99 ve \%90-100 arasında değişen oranlarda benzerlik gösterdiği saptanmıştır. CWP17 izolatı nükleotid ve amino asit düzeyinde en fazla benzerliği Hint izolatı (DQ285569), en az benzerliği ise ABD izolatı (AF127976) ile göstermiştir (Şekil 3). Oluşturulan benzerlik matriksinde alt grup IA ve IB izolatlarının alt grup II izolatlarından oldukça farklı benzerlik değerlerine sahip oldukları görülmektedir. Grupların kendi içlerinde ise oldukça benzer oldukları görülmüştür. Bu bağlamda Ia alt grubunda bulunan izolatlar \%9799, Ib alt grubunda bulunanlar \%94-99 ve son olarak II alt grubunda bulunanlar ise kendi içlerinde \%98-99 oranlarında benzerlik göstermişlerdir. 
Çanakkale ili börülce üretim alanlarında Hıyar mozaik virüsü (Cucumber mosaic virus; CMV)'nün tespiti ve kılıf protein genine göre moleküler karakterizasyonu

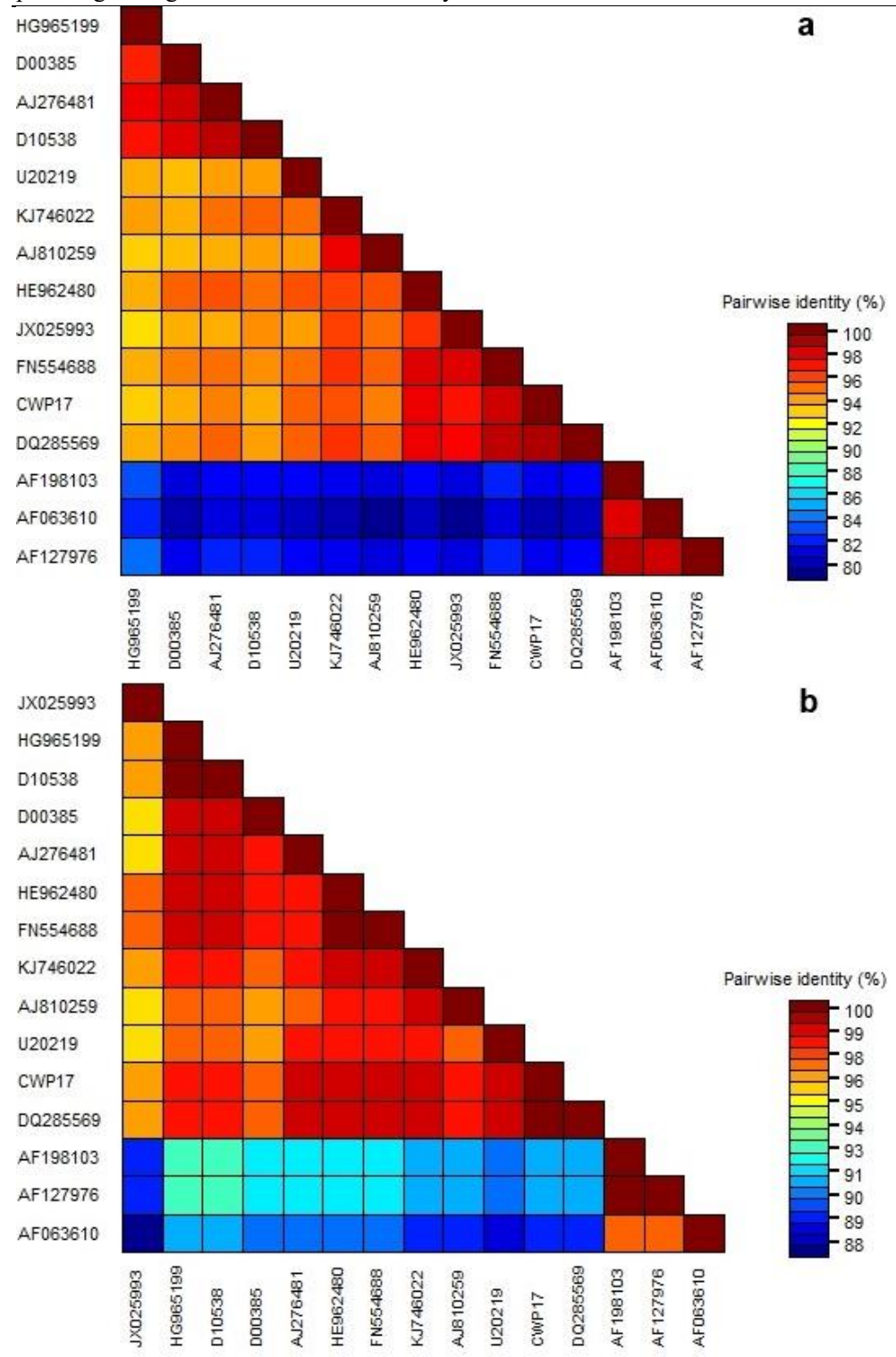

Şekil 3. CWP17 izolatı ile Dünya Hiyar mozaik virüsü (Cucumber mosaic virus; CMV) izolatlarının kılıf protein genleri nükleotid (a) ve aminoasit (b) dizilimleri kullanılarak oluşturulan renklendirilmiş benzerlik matriksi.

CWP17 izolatının dünya izolatları ile göstermiş oldukları filogenetik ilişkiler Şekil 4'de verilmiştir. Neighbor joining ve UPGMA metodu ile oluşturulan her iki filogenetik ağaçta da izolatlar benzer şekilde yer almıştır (benzer topolojilere sahip olmasından dolayı UPGMA metodu ile oluşturulan filogenetik ağaç verilmemiştir). 
CWP17 izolatı oluşturulan her iki filogenetik ağaçta da alt grup IB'de yer almıştır. Roossinck (2002)'nin gerçekleştirmiş olduğu çalışmaya paralel olarak IB izolatlarının çok büyük bir kısmının Asya orijinli olduğu görülürken, IA izolatlarının ise dünyanın farklı bölgelerinden elde edilen izolatlardan oluştuğu görülmüştür. Ülkemizde biber, domates ve kavun bitkilerinde CMV enfeksiyonunun karakterizasyonu amacı ile gerçekleştirilen bir çalışmada CMV izolatlarının alt grup IA'ya ait olduğu bulunmuştur (Çağlar 2006). Her iki çalışmada Türkiye'de gerçekleştirilmesine rağmen, aynı bölge izolatlarının farklı alt gruplarda olabileceği bilinmektedir (Nouri et al. 2014, Eyvazi et al. 2015, Ohshima et al. 2016). Salem et al. (2010) ise börülcede CMV alt grup IB izolatının varlığını bildirmesi, CMV izolatlarının alt gruplarının konukçuya göre farklılaşmış olabileceği sonucunu doğurmaktadır.

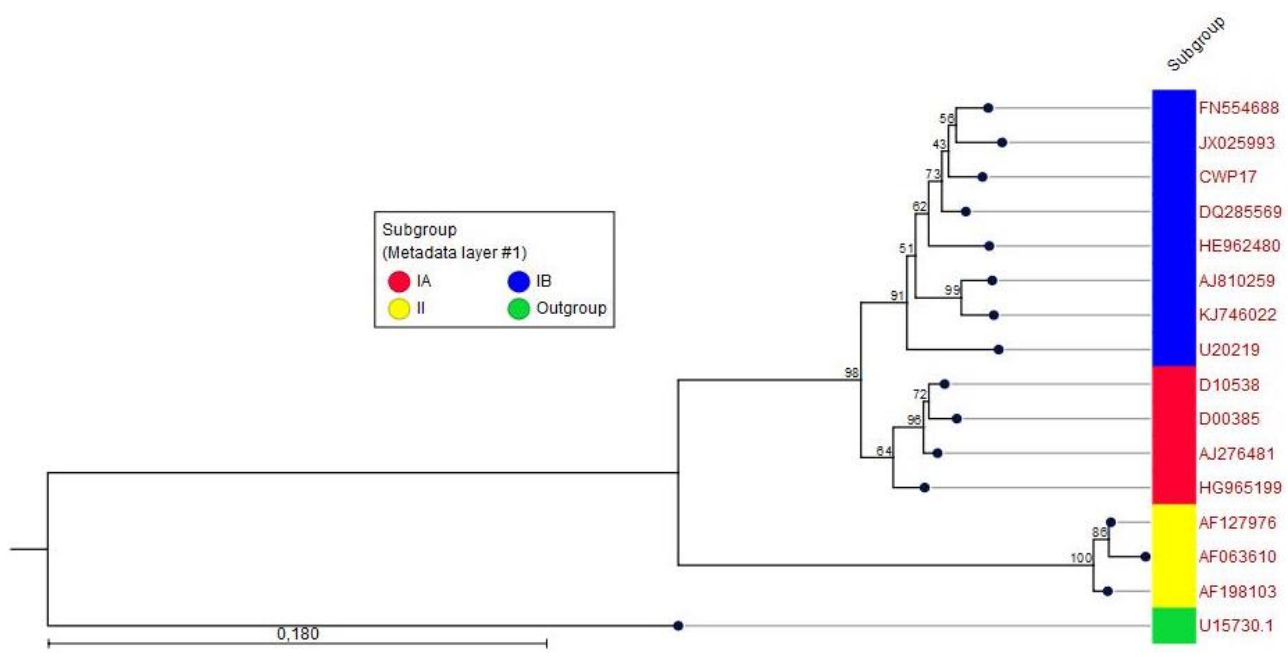

Şekil 4. CWP17 ve Dünya Hlyar mozaik virüsü (Cucumber mosaic virus; CMV) izolatları kılıf protein genleri nükleotid dizilimleri kullanılarak oluşturulan filogenetik ağaç.

Ohshima et al. (2016), Türk Brassicaceae familyası bitkilerinden elde ettiği 7 CMV izolatını da kullandığı moleküler evrim çalışmasında, Türk izolatlarının hepsinin RNA1 ve RNA2'nin nt dizilimlerine göre alt grup IA'da yer aldığını, RNA3'ün nt dizilimine göre ise 2 izolatın alt grup IB'de yer aldığını belirleyerek bu izolatların genomik segmentlerinde farklılıklar tespit etmişlerdir. Fakat 1 a ve $2 \mathrm{a}$ açık okuma bölgelerine (Open Reading Frame; ORF) göre ise tüm Türk izolatlarının IA alt grubunda yer aldığını belirtmişlerdir. Bu bilgiler ışığında CWP17 izolatının IB alt grubunda yer almasına rağmen, 3 RNA bölgesi içinde tüm genom analizlerinin yapılmasının gerekli olduğuna inanılmaktadır. Bununla birlikte CWP17 izolatının, Türkiye için börülceden elde edilen ilk izolat olması nedeni ile tüm RNA segmentlerine göre alt grup IB'de yer alması da olasıdır. Sonuç olarak CMV izolatlarının moleküler profillerinin belirlenmesinde, çok sayıda farklı konukçulardan elde edilmiş ve tüm RNA bölgelerinin ve ORF'lerinin sekans dizilerine dayanan analizlerinin yapılmasının gerekli olduğu düşünülmektedir. 
Çanakkale ili börülce üretim alanlarında Hıyar mozaik virüsü (Cucumber mosaic virus; CMV)'nün tespiti ve kılıf protein genine göre moleküler karakterizasyonu

Oluşturulan filogenetik ağaçtaki gruplara göre; grupların kendi içinde ve birbirleri ile göstermiş oldukları evrimsel farkl11ıklar belirlenmiştir (Çizelge 3). Çizelge 3 incelendiğinde kendi içlerinde evrimsel açıdan en yakın olan izolatların IA grubunda olduğu görülmektedir. Bununla birlikte alt grup II ile IA ve IB alt grupları arasında elde edilen değerlerde filogenetik ağaçta oluşan grupların doğruluğunu teyit etmektedir. Benzer hesaplamalar Turnip mosaic virus (TuMV) izolatları içinde yapılarak filogenetik ağaçtaki grupların doğruluğunu teyit etmek amacı ile de kullanılmıştır (Zhu et al. 2016).

Çizelge 3. Gruplar içi ve arası evrimsel farklılık dereceleri

\begin{tabular}{|l|l|l|l|}
\hline Alt Gruplar & II & IA & IB \\
\hline II & $\mathbf{0 . 0 1 9} *$ & & \\
\hline IA & 0.126 & $\mathbf{0 . 0 1 4}$ & \\
\hline IB & 0.126 & 0.026 & $\mathbf{0 . 0 2 3}$ \\
\hline
\end{tabular}

*Koyu karakterler grupların kendi içlerindeki evrimsel farklılık derecelerini göstermektedir.

Gerçekleştirilen bu çalışma ile Türkiye'de ilk kez CMV enfeksiyonu ticari olarak börülce yetiştiriciliği yapılan alanlarda doğal enfeksiyon olarak tespit edilmiştir. Aynı zamanda gerçekleștirilen moleküler karakterizasyon çalışmaları ile de CWP17 izolatının alt grup IB'de yer aldığ 1 belirlenmiştir. Bununla birlikte daha geniş alanlardan elde edilen CMV izolatlarının biyolojik ve moleküler karakterizasyonunun gerçekleştirilmesi gerektiğine inanılmaktadır. Ayrıca fasulye alanlarında CMV enfeksiyonuna rastlanılmaması nedeni ile fasulye alanlarında enfeksiyon oluşturan diğer etmenlerin tanılanmasına da öncelik verilmesi gerektiği düşünülmektedir.

\section{KAYNAKLAR}

Beler Ö. ve Açıkgöz S. 2005. Ege ve Marmara Bölgelerindeki zeytin fidanlıkları ve ağaçlarında görülen bazı virüs hastalıklarının ELISA testi ile saptanması. ADÜ Ziraat Fakültesi Dergisi, 2 (1), 79-84.

Çağlar B.K. 2006. Hiyar mozaik virüsü (CMV)'nün kavun (CMV-K), domates (CMV-D), biber (CMV-B) izolatlarının biyolojik, serolojik, moleküler yöntemlerle karakterizasyonu ve satellit RNA'lerin virüs üzerindeki etkisi. Fen Bilimleri Enstitüsü, Çukurova Üniversitesi, Doktora Tezi, 89s.

Clark M.F. and Adams A.N. 1977. Characteristics of the microplate method of enzymelinked immunosorbent assay for the detection of plant viruses. Journal of General Virology, 34, 475-483.

Çulal-Kılıç H. ve Yardımcı N. 2012. Burdur Çine Ovası fasulye alanlarında Hıyar mozaik virüsü. Mehmet Akif Ersoy Üniversitesi, Fen Bilimleri Enstitüsü Dergisi, 3 (2), 1215.

Ergun M., Semih E. and Paylan I.C. 2013. Cucumber mosaic virus in globe artichoke in Turkey. Canadian Journal of Plant Pathology, 35 (4), 514-517. 
Erkan S., Gümüş M., Paylan İ.C., Duman İ. ve Ergün M. 2013. İzmir ili ve çevresindeki bazı kışlı sebzelerde görülen viral etmenlerin saptanması. Ege Üniv. Ziraat Fak. Derg., 50 (3): 311-322.

Eyvazi A., Dizadji A., Rastgou M. and Koohi-Habibi M. 2015. Bioassay and phylogeny of five Iranian isolates of Cucumber mosaic virus from different hosts based on CP gene sequence. Plant Protection Science, 51 (4), 200-207.

Gökdağ S., Karanfil A. ve Korkmaz S. 2016. Çanakkale ili ıspanak alanlarındaki Şalgam mozaik virüsü ve Hryar mozaik virüsü varlığının belirlenmesi. Bahçe, özel sayı (cilt II), 166-170.

Gümüş M., Erkan S. ve Tok S. 2004. Bazı kabakgil türlerinin tohumlarındaki viral etmenlerin saptanması üzerinde araştırmalar. Ege Üniv. Ziraat Fak. Derg., 41 (1), 49-56.

Güzel O. and Arl1-Sökmen M. 2003. Determination of some viruses infecting common bean (Phaseoulus vulgaris L.) and their incidences in seed lots in Samsun province. J. Turk. Phytopathology, 32 (2), 99-106.

Karanfil A., Soylu B. ve Korkmaz S. 2016. Çanakkale ili ve ilçelerindeki soğanlı süs bitkilerinde Hiyar mozaik virüsü enfeksiyonunun serolojik ve moleküler yöntemler ile araştırılması. Trakya University Journal of Natural Sciences, 17 (2), 105-110.

Kilic C.H., Yardimci N., Acikyureki S. and Uzal A. 2015. Detection of BCMV, AMV and CMV by DAS-ELISA and immunocapture-RT-PCR in bean-growing areas in the West Mediterranean Region, Turkey. Fresenius Environmental Bulletin, 24 (5), 1752-1756.

Kumar S., Stecher G. and Tamura K. 2016. MEGA7: Molecular Evolutionary Genetics Analysis Version 7.0 For Bigger Datasets. Molecular Biology and Evolution., 33, 1870-1874.

Kutluk-Yılmaz N.D., Gümüş M. ve Erkan S. 2002. Tokat ilinde fasulye tohumlarındaki viral etmenlerin saptanması üzerinde araştırmalar. Ege Üni. Ziraat Fak. Derg., 39 (3), 49-55.

Mohammadi K., Hajizadeh M. and Koolivand D. 2016. Detection and identification of four vegetable fruit viruses in West and Northwest of Iran. Iranian Journal of Plant Pathology, 52 (2), 279-288.

Muhire B.M., Varsani A. and Martin D.P. 2014. SDT: A virus classification tool based on pairwise sequence alignment and identity calculation. Plos One, 9 (9), 1-8.

Nouri S., Arevalo R., Falk B.W. and Groves R.L. 2014. Genetic structure and molecular variability of Cucumber mosaic virus isolates in the United States. Plos One, 9 (5), e96582.

Ohshima K., Matsumoto K., Yasaka R., Nishiyama M., Soejima K., Korkmaz S., Ho S.Y.W., Gibbs A.J. and Takeshita M. 2016. Temporal analysis of reassortment and molecular evolution of Cucumber mosaic virus: Extra clues from its segmented genome. Virology, 487, 188-197. 
Çanakkale ili börülce üretim alanlarında Hıyar mozaik virüsü (Cucumber mosaic virus; CMV)'nün tespiti ve kılıf protein genine göre moleküler karakterizasyonu

Palukaitis P. and Garcia-Arenal F. 2003. Cucumber mosaic virus. AAB. Descriptions of Plant Viruses, No: 400.

Palukaitis P., Roossinck M.J., Dietzgen R.G. and Francki R.I. 1992. Cucumber mosaic virus. Advances in Virus Research, 41, 281-348.

Paylan I.C., Erkan S., Cetinkaya N., Ergun M. and Pazarlar S. 2014. Effects of different treatments on the inactivation of various seedborne viruses in some vegetables. Ozone-Science \& Engineering, 36 (5), 422-426.

Roossinck M.J. 2002. Evolutionary history of Cucumber mosaic virus deduced by phylogenetic analyses. Journal of Virology, 76 (7), 3382-3387.

Roossinck M.J., Zhang L. and Hellwald K.H. 1999. Rearrangements in the 5' nontranslated region and phylogenetic analyses of Cucumber mosaic virus RNA 3 indicate radial evolution of three subgroups. Journal of Virology, 73 (8), 6752-6758.

Salem N.M., Ehlers J.D., Roberts P.A. and Ng J.C.K. 2010. Biological and molecular diagnosis of seedborne viruses in cowpea germplasm of geographically diverse SubSaharan Origins. Plant Pathology, 59, 773-784.

Sarı S. 2015. Samsun ilinde yetiştirilen yazlık sebzelerde enfeksiyon oluşturan Cucumber mosaic virus (CMV) izolatlarının karakterizasyonu ve konukçu-simptom-satellit RNA ilişkilerinin araştırılması. Fen Bilimleri Enstitüsü, Ondokuz Mayıs Üniversitesi, Yüksek Lisans Tezi, 89s.

Sertkaya G. 2015. Hatay ili marul ve ıspanak alanlarında bazı virüslerin araştırılması. Mustafa Kemal Üniversitesi, Ziraat Fakültesi Dergisi, 20 (1), 7-12.

Zhu F., Sun Y., Wang Y., Pan H., Wang F., Zhang X., Zhang Y. and Liu J. 2016. Molecular characterization of the complete genome of three basal-BR isolates of Turnip mosaic virus infecting Raphanus sativus in China. International Journal of Molecular Sciences, 17, 888; doi:10.3390/ijms17060888.

Zitter T.A. and Murphy J.A. 2009. Cucumber mosaic virus. The Plant Health Instructor, DOI: 10.1094/PHI-I-2009-0518-01. 